\title{
COMPARATIVE STUDY OF TRANSVERSUS ABDOMINIS PLANE (TAP) BLOCK VERSUS LOCAL ANAESTHETIC WOUND INFILTRATION FOR POST-OPERATIVE PAIN RELIEF
}

\author{
Debabrata Nath Sharma ${ }^{1}$ Kaberi Sarkar², Rusikesh Satapathy33, Pavan H. R4 \\ ${ }^{1}$ Associate Professor, Department of Anaesthesiology, MKCG Medical College and Hospital, Berhampur, Odisha. \\ $22^{\text {nd }}$ Year Junior Resident, Department of Anaesthesiology, MKCG Medical College and Hospital, Berhampur, Odisha. \\ ${ }_{3}^{2} 2^{\text {nd }}$ Year Junior Resident, Department of Anaesthesiology, MKCG Medical College and Hospital, Berhampur, Odisha. \\ ${ }^{4} 3^{\text {rd }}$ Year Junior Resident, Department of Anaesthesiology, MKCG Medical College and Hospital, Berhampur, Odisha.
}

ABSTRACT

\section{BACKGROUND}

A major contributor to pain experienced after abdominal surgeries is pain from the incision made on abdominal wall. TAP blocks and local anaesthetic wound infiltration are believed to provide improved post-operative pain relief.

The aims of this study is to study and compare the effects of Transversus Abdominis Plane (TAP) block with local anaesthetic wound infiltration for analgesia post-operatively in female patient undergoing abdominal hysterectomy.

\section{MATERIALS AND METHODS}

A randomised, prospective and double-blinded study was carried out taking 90 patients of ASA Grade I and II of age group between 35 and 60 yrs. randomly allocated into two Groups. Group I- Patient received $20 \mathrm{~mL}$ of local anaesthetic infiltration at the surgical site at the end of surgery with $0.5 \mathrm{mg} / \mathrm{kg}$ of $0.5 \%$ Inj. Bupivacaine. Group II- Patient received $20 \mathrm{~mL}$ of Transversus Abdominis Plane (TAP) block at the end of surgery $0.5 \mathrm{mg} / \mathrm{kg}$ of $0.5 \%$ Inj. Bupivacaine.

\section{RESULTS}

TAP block produced prolonged and effective post-operative analgesia, which lasted longer than produced by local anaesthetic wound infiltration.

\section{CONCLUSION}

Transversus abdominis plane block produced prolonged and effective postoperative analgesia as compared to local anaesthetic wound infiltration and it reduces requirement of other analgesic drugs.

\section{KEYWORDS}

Tap Block, Local Anaesthetic Wound Infiltration, Post-Operative Analgesia.

HOW TO CITE THIS ARTICLE: Sharma DN, Sarkar K, Satapathy R, et al. Comparative study of transversus abdominis plane (TAP) block versus local anaesthetic wound infiltration for post-operative pain relief. J. Evolution Med. Dent. Sci. 2017;6(61):4470-4474, DOI: $10.14260 /$ Jemds/2017/966

\section{BACKGROUND}

Poorly controlled acute pain after abdominal surgery is associated with a variety of unwanted post-operative consequences including patient's distress, respiratory complications, delirium, myocardial ischaemia, prolonged hospital stay and increased likelihood of chronic pain. A major contributor to the pain experienced after abdominal surgery is pain from the incision made on the abdominal wall with the remainder resulting from internal visceral trauma. Traditionally, analgesia for abdominal surgery is provided either by systemic drugs such as opioids, ketamine, NonSteroidal Anti-Inflammatory (NSAIDS) or by epidural anaesthesia.

The transversus abdominis plane block was first described by McDonnel et al in 2004,(1) for pain control of procedures involving the anterior abdominal wall.

Financial or Other, Competing Interest: None.

Submission 09-05-2017, Peer Review 18-07-2017,

Acceptance 24-07-2017, Published 31-07-2017.

Corresponding Author:

Dr. Kaberi Sarkar,

MKCG Medical College,

PG Ladies Hostel 2 ,

Berhampur-760004, Odisha.

E-mail:drkaberisarkar@gmail.com

DOI: $10.14260 /$ jemds $/ 2017 / 966$
This technique was improved with a blind landmark technique via the lumbar triangle of Petit.(2) The skin, muscles and parietal peritoneum in this region are innervated by the T7 through L1 nerve roots. T7 gives sensory innervations at the epigastrium, T10 at the umbilicus and L1 at the groin. $.3,4)$ The authors described deposition of local anaesthetic in the plane between the internal oblique and the transversus abdominis muscles, where the terminal branches of the T7 through L1 nerves lie. Since then, the TAP block has been shown to effectively provide analgesia for a variety of abdominal procedures. In 2007, an ultrasound-guided approach was described by Hebbard et al.(5)

The use of opioid analgesics is generally safe and adverse effects do occur, thereby mandating the use of alternative analgesic technique when feasible. In an effort to improve post-operative analgesia while limiting opioid related adverse effects, there continues to be an increased use of multimodal techniques in patients. There can include TAP block as well as wound infiltration with local anaesthetic.

The block has been shown to be useful in upper abdominal surgery, but the upper extent of the block and its use in upper abdominal surgery are controversial.(6,7,8,9) TAP block also has a role as rescue analgesia on awake postoperative patients, who did not receive blocks prior to abdominal surgery.(10) 


\section{MATERIALS AND METHODS}

After obtaining approval from Hospital Ethics Committee and written informed consent, study was carried out from 2015 to 2016 in a tertiary care hospital. The study population included patient of female sex, ASA Grade I and II in the age range 35 to 60 undergoing abdominal hysterectomy under spinal anaesthesia.

The randomised, prospective and double-blinded study was carried out on adult patients who underwent abdominal hysterectomy under spinal anaesthesia and the effect of postoperative analgesia between transversus abdominis plane block and local anaesthetic wound infiltration was compared.

All 90 patients fulfilling inclusion criteria were enrolled for our study. Patients were allocated into two groups alternatively. We selected the patient posted for abdominal hysterectomy under spinal anaesthesia, which was given at L3-L4 IVS level with $3.4 \mathrm{~mL}$ of $0.5 \%$ Bupivacaine heavy.

Group I- Patient received $20 \mathrm{~mL}$ of local anaesthetic infiltration at the surgical site at the end of surgery with 0.5 $\mathrm{mL} / \mathrm{kg}$ of $0.5 \%$ Inj. Bupivacaine. Group II- Patients received $20 \mathrm{~mL}$ of transversus abdominis plane block at the end of surgery with $0.5 \mathrm{mg} / \mathrm{kg}$ of $0.5 \%$ Inj. Bupivacaine.

Drugs solution was prepared by an independent anaesthesiologist not involved in the study. Here both the patient and treating anaesthetist were blind about the study drug injected (i.e. double-blinded study).

\section{Following parameters were studied}

1. Duration of Post-Operative Analgesia- After the TAP block and local wound infiltration, following parameters were assessed.

A- Pain severity was measured using Visual Analogue Scale (VAS) (no pain- 0, worst imaginable- 10).

2. First Rescue Analgesia- It was the time when any analgesic was administered to the patient for the first time after surgery. We have given Inj. Diclofenac $75 \mathrm{mg}$ IV slow in a $100 \mathrm{~mL}$ of NS in post-operative period in the form of a rescue analgesia.

\section{Complication if any.}

\section{Statistical Analysis}

Collected data were analysed with the help of SPSS software version 16. Demographic profile and average time for pain relief profile were compared by t-test. Numerical nonparametric data were compared by Mann-Whitney U test. Nominal and ordinal data were compared by Fisher's exact test. $\mathrm{P}<0.05$ was considered statistically significant.

- If $\mathrm{P}>0.05$, it means that there is no significant difference between the median VAS of two groups studied.

- If $\mathrm{P}<0.05$, it indicates that there is a significant difference at $5 \%$ level of significance.

- If $\mathrm{P}<0.01$, it indicates that the data is significant at $1 \%$ level of significance.

- If $\mathrm{P}<0.001$, it is highly significant.
RESULTS

\begin{tabular}{|c|c|c|c|}
\hline & $\begin{array}{c}\text { Group I } \\
\text { (SA + LA) } \\
\text { (mean } \pm \text { SD) }\end{array}$ & $\begin{array}{c}\text { Group II } \\
\text { (SA + TAP) } \\
\text { (mean } \pm \text { SD) }\end{array}$ & P-value \\
\hline Age in yrs. & $39.07 \pm 14.98$ & $41.03 \pm 14.10$ & $\mathrm{P}>0.05$ \\
\hline Weight in kg & $62.87 \pm 10.12$ & $65.17 \pm 15.95$ & $\mathrm{P}>0.05$ \\
\hline Height in cm & $158.23 \pm 9.64$ & $160.27 \pm 10.82$ & $\mathrm{P}>0.05$ \\
\hline $\begin{array}{c}\text { Duration of } \\
\text { surgery in min }\end{array}$ & $92.10 \pm 9.30$ & $92.73 \pm 12.25$ & $\mathrm{P}>0.05$ \\
\hline
\end{tabular}

Table 1. Demographic Profile

This table shows there is no significant difference in demographic characteristic between the two groups (Compared by t-test).

\begin{tabular}{|c|c|c|}
\hline $\begin{array}{c}\text { Group I } \\
\text { (SA + LA) } \\
\text { (mean } \pm \text { SD) }\end{array}$ & $\begin{array}{c}\text { Group II } \\
\text { (SA + TAP) } \\
\text { (mean } \pm \text { SD) }\end{array}$ & P-value \\
\hline $8.47 \pm 2.85$ & $15.67 \pm 3.22$ & $<0.01^{* *}$ \\
\hline \multicolumn{3}{|c|}{ Table 2. Comparison of Average Time of Request for Pain } \\
Relief (In Hr)
\end{tabular}

**: Significant at $1 \%$ level of significance

The result indicated that there was significant difference in the average time of request for pain relief $(\mathrm{p}<.01)$ (Compared by t-test).

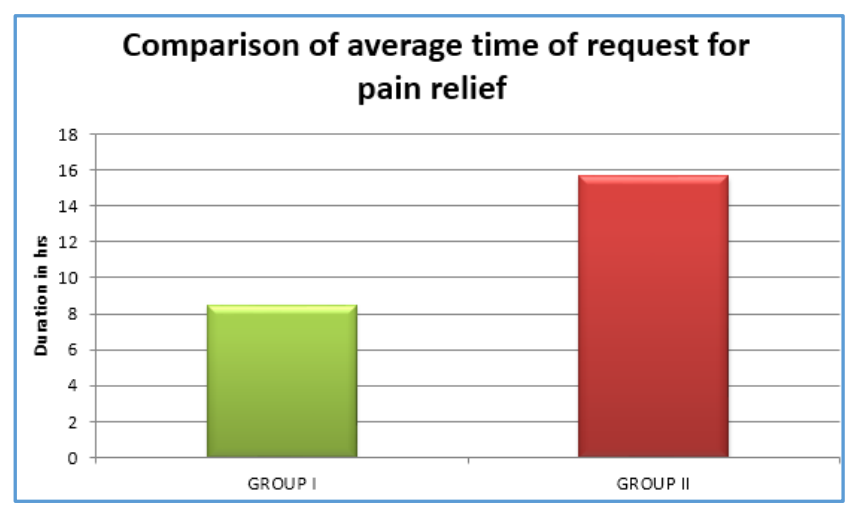

Graph I

\begin{tabular}{|c|c|c|c|c|}
\hline Duration & Group & Median & $\begin{array}{c}\text { IQR } \\
\text { (Q3 - Q1) }\end{array}$ & \begin{tabular}{|c} 
Mann- \\
Whitney \\
Test U-value
\end{tabular} \\
\hline \multirow{2}{*}{0} & $\begin{array}{c}\text { Group I } \\
(\mathrm{SA}+\mathrm{LA})\end{array}$ & 0 & 0 & \multirow{2}{*}{$\begin{array}{c}U=450 \\
P<0.9920\end{array}$} \\
\hline & $\begin{array}{c}\text { Group II } \\
\text { (SA + TAP) }\end{array}$ & 0 & 0 & \\
\hline \multirow{2}{*}{0.5} & $\begin{array}{c}\text { Group I } \\
(\mathrm{SA}+\mathrm{LA})\end{array}$ & 0 & 0 & \multirow{2}{*}{$\begin{array}{c}U=450, \\
P<0.9920\end{array}$} \\
\hline & $\begin{array}{c}\text { Group II } \\
\text { (SA + TAP) }\end{array}$ & 0 & 0 & \\
\hline \multirow{2}{*}{1} & $\begin{array}{c}\text { Group I } \\
(\mathrm{SA}+\mathrm{LA})\end{array}$ & 0 & 0 & \multirow{2}{*}{$\begin{array}{c}U=450 \\
P<0.9920\end{array}$} \\
\hline & $\begin{array}{c}\text { Group II } \\
\text { (SA + TAP) }\end{array}$ & 0 & 0 & \\
\hline \multirow{2}{*}{1.5} & $\begin{array}{c}\text { Group I } \\
(\mathrm{SA}+\mathrm{LA})\end{array}$ & 0 & 0 & \multirow{2}{*}{$\begin{array}{c}U=450, \\
P<0.9920\end{array}$} \\
\hline & $\begin{array}{c}\text { Group II } \\
\text { (SA + TAP) }\end{array}$ & 0 & 0 & \\
\hline 2 & $\begin{array}{c}\text { Group I } \\
(\mathrm{SA}+\mathrm{LA})\end{array}$ & 0 & 0 & $\begin{array}{c}\mathrm{U}=450, \\
\mathrm{P}<0.9920\end{array}$ \\
\hline
\end{tabular}




\begin{tabular}{|c|c|c|c|c|}
\hline & $\begin{array}{c}\text { Group II } \\
(\mathrm{SA}+\mathrm{TAP})\end{array}$ & 0 & 0 & \\
\hline \multirow{2}{*}{3} & $\begin{array}{c}\text { Group I } \\
(\mathrm{SA}+\mathrm{LA})\end{array}$ & 2 & $0(2-2)$ & \multirow{2}{*}{$\begin{array}{l}U=450, P \\
<0.9920\end{array}$} \\
\hline & $\begin{array}{c}\text { Group II } \\
\text { (SA + TAP) }\end{array}$ & 0 & 0 & \\
\hline \multirow{2}{*}{4} & $\begin{array}{c}\text { Group I } \\
\text { (SA + LA) }\end{array}$ & 2 & 0 & \multirow{2}{*}{$\begin{array}{c}U=435 \\
P<0.9920\end{array}$} \\
\hline & $\begin{array}{c}\text { Group II } \\
\text { (SA + TAP) }\end{array}$ & 0 & 0 & \\
\hline \multirow{2}{*}{5} & $\begin{array}{c}\text { Group I } \\
(S A+L A)\end{array}$ & 2 & $2(4-2)$ & \multirow{2}{*}{$\begin{array}{c}U=345 \\
P<0.123\end{array}$} \\
\hline & $\begin{array}{c}\text { Group II } \\
\text { (SA + TAP) }\end{array}$ & 0 & 0 & \\
\hline \multirow{2}{*}{6} & $\begin{array}{c}\text { Group I } \\
(S A+L A)\end{array}$ & 2 & $2(4-2)$ & \multirow{2}{*}{$\begin{array}{c}\mathrm{U}=135 \\
\mathrm{P}<0.00001\end{array}$} \\
\hline & $\begin{array}{c}\text { Group II } \\
\text { (SA + TAP) }\end{array}$ & 0 & 0 & \\
\hline \multirow{2}{*}{7} & $\begin{array}{c}\text { Group I } \\
(\mathrm{SA}+\mathrm{LA})\end{array}$ & 4 & $2(4-2)$ & \multirow{2}{*}{$\begin{array}{c}\mathrm{U}=60 \\
\mathrm{P}<0.00001\end{array}$} \\
\hline & $\begin{array}{c}\text { Group II } \\
\text { (SA + TAP) }\end{array}$ & 0 & 0 & \\
\hline \multirow{2}{*}{8} & $\begin{array}{c}\text { Group I } \\
(\mathrm{SA}+\mathrm{LA})\end{array}$ & 4 & $2(6-4)$ & \multirow{2}{*}{$\begin{array}{c}\mathrm{U}=15 \\
\mathrm{P}<0.00001\end{array}$} \\
\hline & $\begin{array}{c}\text { Group II } \\
\text { (SA + TAP) }\end{array}$ & 0 & 0 & \\
\hline \multirow{2}{*}{9} & $\begin{array}{c}\text { Group I } \\
(\mathrm{SA}+\mathrm{LA})\end{array}$ & $\begin{array}{c}6 \text { rescue } \\
\text { analgesia }\end{array}$ & $0(6-6)$ & \multirow{2}{*}{$\begin{array}{c}\mathrm{U}=135 \\
\mathrm{P}<0.00001\end{array}$} \\
\hline & $\begin{array}{c}\text { Group II } \\
\text { (SA + TAP) }\end{array}$ & 0 & 0 & \\
\hline \multirow{2}{*}{10} & $\begin{array}{c}\text { Group I } \\
(\mathrm{SA}+\mathrm{LA})\end{array}$ & 2 & $2(4-2)$ & \multirow{2}{*}{$\begin{array}{c}U=225 \\
P<0.0009\end{array}$} \\
\hline & $\begin{array}{c}\text { Group II } \\
\text { (SA + TAP) }\end{array}$ & 0 & 0 & \\
\hline \multirow{2}{*}{11} & $\begin{array}{c}\text { Group I } \\
(S A+L A)\end{array}$ & 2 & 0 & \multirow{2}{*}{$\begin{array}{c}U=435 \\
P<0.8336\end{array}$} \\
\hline & $\begin{array}{c}\text { Group II } \\
(\mathrm{SA}+\mathrm{TAP})\end{array}$ & 0 & 0 & \\
\hline \multirow{2}{*}{14} & $\begin{array}{c}\text { Group I } \\
(\mathrm{SA}+\mathrm{LA})\end{array}$ & & & \multirow{2}{*}{$\begin{array}{c}U=60, \\
P<0.00001\end{array}$} \\
\hline & $\begin{array}{c}\text { Group II } \\
\text { (SA + TAP) }\end{array}$ & 2 & $2(4-2)$ & \\
\hline \multirow{2}{*}{15} & $\begin{array}{c}\text { Group I } \\
(\mathrm{SA}+\mathrm{LA})\end{array}$ & & & \multirow{2}{*}{$\begin{array}{c}\mathrm{U}=0, \\
\mathrm{P}<0.00001\end{array}$} \\
\hline & $\begin{array}{c}\text { Group II } \\
\text { (SA + TAP) }\end{array}$ & 4 & $4(6-2)$ & \\
\hline \multirow{2}{*}{16} & $\begin{array}{c}\text { Group I } \\
(\mathrm{SA}+\mathrm{LA})\end{array}$ & & & \multirow{2}{*}{$\begin{array}{c}\mathrm{U}=15, \mathrm{P} \\
<0.00001\end{array}$} \\
\hline & $\begin{array}{c}\text { Group II } \\
\text { (SA + TAP) }\end{array}$ & $\begin{array}{c}6 \text { rescue } \\
\text { analgesia }\end{array}$ & $2(6-4)$ & \\
\hline
\end{tabular}

The above table indicated descriptive statistics for VAS score at various durations. The result indicated that there was a significant difference in VAS score of each group at various durations. In Group I the VAS score was higher during 7 to 9 hours, in Group II the VAS score was higher during 14 to 16 hours. The results are also shown in the graph below.

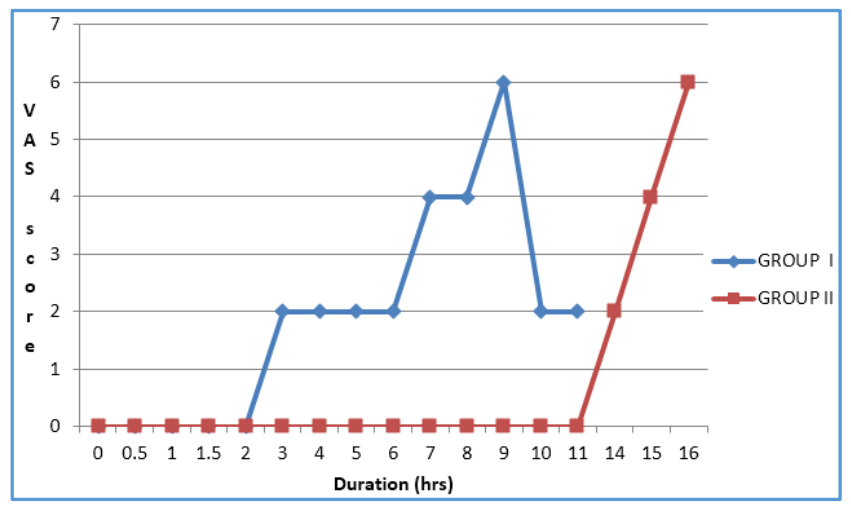

Graph II. VAS Score at Various Durations

\section{DISCUSSION}

Peripheral nerve block is an alternative means of providing analgesia by anaesthetising the sensory nerve carrying pain impulse from the incision site to the spinal cord and brain. The TAP block is a peripheral nerve block, which anaesthetises the abdominal wall. Although, this technique was first specifically described in 2004, variation has been used by anaesthetists for decided without becoming widely adopted. Its proponents suggest that analgesia provided by TAP block is equal or superior to that provided by systemic opioids such as morphine. It is also claimed that postoperative opioids consumption and opioid-derived adverse effects can be reduced. Furthermore, the TAP block may have a lower risk of complications and greater acceptability to patients than epidural analgesia.

In 1987 Atkinson R, Rushman G and Lee J, published the use of the abdominal field blocks.(11)

In 1920 Tverskoy M, Cozacov C, Ayache M, Brably EL Jr, Kissin did a research work regarding postoperative pain after inguinal herniorrhaphy with different types of anaesthesia. This randomised clinical trial concluded that postoperative pain after inguinal herniorrhaphy can be significantly decreased if the surgery is performed with local infiltration anaesthesia or spinal anaesthesia instead of general anaesthesia. Perhaps because neural blockade prevents nociceptive impulses from entering the central nervous system during and immediately after surgery and thus suppresses formation of the sustained hyperexcitable state in the central nervous system that is responsible for the maintenance of postoperative pain.(12)

In another study by Erichsen CJ, Vibits H, Dahl JB, Kehelet H, Acta Anesthesiol Scand in 1995 did a double-blind, randomised study in which 32 patients scheduled for elective inguinal herniotomy under general anaesthesia received subcutaneous infiltration with $40 \mathrm{~mL}$ ropivacaine $2.5 \mathrm{mg} / \mathrm{mL}$ or bupivacaine. Post-operative pain intensity was assessed repeatedly for 24 hours at rest, during cough and movement on a Visual Analogue Scale (VAS) and by means of pressure algometry. No differences between pain intensities or wound tenderness were found between the groups. The demand for analgesics was similar in the two groups. It was concluded that incisional ropivacaine is as effective as bupivacaine in the management of post-herniotomy pain.(13)

Not a long ago, O'Donnell B did a trial of TAP block in open retropubic prostatectomy in 2006. In this, TAP block 
was performed on 12 open retropubic prostatectomy patients. The blocks were performed with $20 \mathrm{~mL}$ of $0.375 \%$ bupivacaine to each side pre-operatively. Minimal morphine consumption was demonstrated (mean of $6.33 \mathrm{mg}$ in 48 hours with a range of $0-15 \mathrm{mg}$ ). There were no adverse effects reported from the block.(14)

In 2007 Hebbard P, Fujiwara Y, Royse C published their work on USG-guided TAP block.(15)

Then in 2007 McDonnell J, O’Donnell, Brain M, Curley G, Heffeman A, Power C, Laffey J examined the TAP block efficacy in a randomised clinical trial of 32 patients undergoing large bowel resection via midline abdominal incision. The patients were randomised to receive standard care (PCA, regular non-steroidal anti-inflammatory drugs and paracetamol) or TAP block with the landmark technique (20 $\mathrm{mL} 0.375 \%$ levobupivacaine). They found the TAP group had decreased Visual Analogue Scale (VAS) pain scores at emergence and at all times measured postoperatively up to 24 hours. There were no complications from the blocks and a high reported patient satisfaction level in the TAP group.(16)

In 2007 McDonnell J, O'Donnell B, Farrell T, Gough N, Tuite D, Power C, Laffey J published a cadaveric study that showed spread of methylene blue dye into the transversus abdominis plane.(17)

In 2007 Ausems ME, Hulsewe KW, Hooymans PM, Hoofwijk AG studied the postoperative analgesia requirements at home after inguinal hernia repair and effects of wound infiltration on postoperative pain.(18)

Recently in 2008 Gucev G, Yasui G, Chang TY, Lee J published the work on use of TAP blocks after caesarean section, describes placement of TAP catheters under ultrasound guidance in three case reports. Continuous infusions of $0.2 \%$ ropivacaine at $4 \mathrm{~mL}$ /hours was used for 24 hours. The reported benefits of the block included low pain scores, minimal use of supplemental opioid and absence of postoperative nausea and vomiting.(19)

Similarly on McDonnell J, Curley G, Carney J, Benton AJ, Maharaj C, Laffey J research work in 2008, there were no complications from the block.(20)

Our study indicated that there were significant differences in each group in aspect of postoperative analgesia. All these data were statistically significant, which showed that request for pain relief and VAS of Group 2 was prolonged when compared to Group 1.

\section{CONCLUSION}

TAP block produced prolonged and effective postoperative analgesia, which lasts longer as compared to local anaesthetic wound infiltration. Moreover, it is a very effective way of providing analgesic drugs like NSAIDS, opioids, etc. in postoperative period.

Our research work suggests that TAP block constitutes an effective analgesic option in patients undergoing surgery for abdominal hysterectomy as compared to patient who received local wound infiltration.

\section{REFERENCES}

[1] Rafi AN. Abdominal field block: a new approach via the lumbar triangle. Anaesthesia 2001;56(10):1024-6.
[2] McDonnell J, O'Donnell, Tuite D, et al. The regional abdominal field infiltration (R.A.F.I.) technique: computerized tomographic and anatomical identification of a novel approach to the transversus abdominis neuro-vascular fascial plane. Anesthesiology 2004;101:A899.

[3] Lee TH, Barrington MJ, Tran TM, et al. Comparison of extent of sensory block following posterior and subcostal approaches to ultrasound guided transversus abdominis plane block. Anaesth Intensive Care 2010;38(3):452-60.

[4] Borglum J, Maschmann C, Belhage B, et al. Ultrasound guided bilateral dual transversus abdominis plane block: a new four point approach. Acta Anaesthesiol Scand 2011;55(6):658-63.

[5] Hebbard P, Fujiwara Y, Shibata Y, et al. Ultrasound guided transversus abdominis plane (TAP) block. Anaesthesia and Intensive Care 2007;35(4):616-7.

[6] Bharati N, Kumar P, Bala I, et al. The efficacy of a novel approach to transversus abdominis plane block for post-operative analgesia after colorectal surgery. Anaesth Analg 2011; 112(6):1504-8.

[7] Young MJ, Gorlin AW, Modest VE, et al. Clinical implications of Transversus Abdominis Plane Block in adults. Anaesthesiol Res Pract Article ID 731645 2012; 2012: p. 11.

[8] Ismail S. Multinodal analgesia for cesarean section: evolving role of transversus abdominis plane block. J Obstet Anaesth Crit Care 2012; 2(2):67-8.

[9] Yu N, Long X, Lujan-Hernandez JR, et al. Transversus abdominis plane block versus local anaesthetic wound infiltration in lower abdominal surgery: a systematic review and meta-analysis of randomized controlled trials. BMC Anesthesiol 2014; 14:121.

[10] Shrivastava U, Verma S, Singh TK, et al. Efficacy of transversus abdominis plane block for post cesarean delivery analgesia: a double blind, randomized trial. Saudi J Anaesth 2015; 9(3):298-302.

[11] Atkinson R, Rushman G, Lee J. A synopsis of anaesthesia. 10 $0^{\text {th }}$ edn. Bristol: Wright 1987:637-40.

[12] Tverskoy M, Cozacov C, Ayache M, et al. Postoperative pain after inguinal herniorrhaphy with different types of anaesthesia. Anesth Analg 1990; 70(1):29-35.

[13] O'Donnell BD, McDonnell JG, McShane AJ. The transversus abdominis plane (TAP) block in open retropubic prostatectomy. Regional Anaesthesia and Pain Medicine 2006; 31(1):91.

[14] Hebbard P. 2007. www.heartweb.com.au/downloads TAP block.pdf.

[15] McDonnell J, O’Donnell B, Curley G, et al. The analgesic efficacy of TAP block after abdominal surgery: a prospective randomized controlled trial. Anaesthesia and Analgesia 2007; 104(1):193-7.

[16] McDonnell JG, O'Donnell BD, Farrell T, et al. Transversus abdominis plane block: a cadaveric and radiological evaluation. Regional Anaesthesia and Pain Medicine 2007; 32(5):399-404.

[17] Shibata Y, Sato Y, Fujiwara Y, et al. Transversus abdominis plane block. Anesthesia and Analgesia 2007; 105(3):883. 


\section{Jemds.com}

[18] Hebbard P. Subcostal transversus amdominis plane block under ultrasound guidance. Anaesthesia and Analgesia 2008; 106(2):674-5.

[19] Laffey JG, McDonnell JG. Subcostal Transversus abdominis plane block under ultrasound guidance. Anaesthesia and Analgesia 2008;106(2):675.

\section{Original Research Article}

[20] Farooq M, Carey M. A case of liver trauma with a blunt regional anaesthesia needle while performing transversus abdominis plane block. Regional Anaesthesia and Pain Medicine 2008;33(3):274-5. 